\title{
Spanish Business Schools paradox and the accreditation system expiry: when the success becomes a risk
}

\author{
Antonio Sánchez-Bayón*a1 / Estrella Trincado Aznarb \\ aUniversidad Rey Juan Carlos, Departamento de Economía de la Empresa (ADO), Economía Aplicada II y Fundamentos del \\ Análisis Económico, Paseo de Artilleros, s/n, 28032 Madrid, Spain \\ bUniversidad Complutense de Madrid, Departamento de Economía Aplicada, Estructura e Historia, Campus de Somosaguas, \\ 28223 Pozuelo de Alarcón, Spain
}

Received: 4 June 2020 / Accepted: 20 November 2020

\begin{abstract}
This paper is an analytical-empirical review of the evolution of Spanish Business Schools and how they have been affected by the accreditation system. This system has made it possible for the Spanish Business Schools to rank among the best (10 of them are in the World top-25 and 4 have been accredited with the triple crown, which is the highest distinction). However, it has also led to the denaturalization of the Business Schools (B-Schools), which have been "devoured" by the Schools of Economics and Business at universities. In addition, the accreditation system has entailed an increase in costs (opportunity, marginal, sunk costs and so on). An explanation of the Spanish B-Schools paradox is offered in the article: the more accreditations achieved, the more difficult it is to maintain them, due to contradictions in the compliance regulation and to the difficulty in updating academic programmes since their success and assimilation into the welfare state economy is a risk for B-Schools and their adaptation to digital economy. Finally, the paper gives some keys to correct the problem detected and thus to adapt B-Schools to the emerging wellbeing economics, a new stage of the digital economy.
\end{abstract}

\section{Keywords}

Business School / Accreditations system / Compliance / Welfare state economy / Wellbeing economics.

\section{0 paradoxo das escolas de negocios españolas e a caducidade do sistema de acreditacións: cando o éxito se converte en risco}

\section{Resumo}

Trátase dun artigo analítico-empírico sobre economía institucional que realiza un balance do desenvolvemento das escolas de negocios en España e de como lles afectou o sistema de acreditacións. Aclárase como o sistema de acreditacións, aínda que serviu para situar ás escolas de negocios entre as mellores (10 delas no top 25 mundial e 4 acreditadas coa tripre coroa, que é a máxima distinción), tamén provocou a súa desnaturalización ao confundirse coas facultades de economía e empresa, ademais de aumentar os custos (oportunidade, marxinais, afundidos, etcétera). Tamén se explica en que consiste o paradoxo das escolas de negocios españolas: cantas máis acreditacións se acadan, máis difícil é mantelas debido ás contradicións no seu cumprimento normativo e á dificultade para actualizar os programas académicos), xa que o seu éxito para a economía do benestar pode ser o risco para a economía dixital. 0 estudo ofrece algunhas claves para corrixir o problema detectado e así adaptar as escolas de negocios á economía emerxente do benestar persoal, unha nova etapa da economía dixital.

\section{Palabras clave}

Escolas de negocios / Sistema de acreditacións / Cumprimento normativo / Economía de benestar estatal / Economía de benestar persoal.

JEL Codes: A12, B2, I31, M14, 033, Z1.

\footnotetext{
* A. Sánchez-Bayón: antonio.sbayon@urjc.es (corresponding author); E. Trincado: estrinaz@ccee.ucm.es

${ }^{1}$ Research part of Sánchez-Bayón's PhD dissertation in Economics (UVA) \& supported by GESCE-URJC \& TRANS-REAL LABUVA.
} 


\section{Introduction}

In Spain, there are more than one hundred Business Schools recognized in the official educational system. A third of them are included in international rankings (e.g. Financial Times, Fortune, Bloomberg, The Economist, Global MBA, MBA Today, QS MBA), and they have achieved international accreditations, e.g. Association to Advance Collegiate Schools of Business (AACSB), Association of MBAs (AMBA), European Foundation for Management Development-Qualitative Improvement Systems (EQUIS). There are also four B-Schools in the world's top 25 (top 10 in Europe) and with the triple crown (the three main accreditations quoted): Escuela Superior de Administración y Dirección de Empresas (ESADE), Instituto de Empresa (IE), Instituto de Estudios Superiores de Empresa (IESE), and École Supérieure de Commerce de Paris in Madrid (ESCP-Madrid) (see, Peña, 2018). In Table 1 we summarize the accreditation systems for B-Schools.

Table 1. Accreditation systems for B-Schools

Triple crown (international private alliance): recognition for 90 B-Schools in the world (less than $1 \%$ of all B-Schools in the World). This distinction includes:

- AACSB (Association to Advance Collegiate Schools of Business): it is an American professional organization, founded 1916 to provide accreditations for B-Schools (members: over 1,600; accredited: over 850).

- AMBA (Association of MBAs): it is a global organization founded in UK in 1967 (members: over 30,000; accredited: over 250).

- EQUIS (European Foundation for Management Development-Qualitative Improvement Systems): it is an evaluation system for B-Schools supported by a Belgician foundation (172 B-Schools accredited in 41 countries).

Official agencies

- ENQA (European Association for Quality Assurance in Higher Education): EU body founded in 2000 which published the first guide of European higher education standards.

- CHEA (Council for Higher Education Accreditation): it is part of the U.S. Secretary of Education.

- ANECA (National Agency for Quality Assessment and Accreditation): it is an agency related with the Spanish Ministry of Education \& Universities.

Spanish B-Schools with triple crown + ANECA

- ESADE (Escuela Superior de Administración y Dirección de Empresas): Higher School of Business Administration and Management, founded in 1958 by the Society of Jesus, located in Barcelona and Madrid (close to the Univ. Ramón Llull -Jesuit origin).

- IE (Instituto de Empresa): founded in 1973 and transformed into a private university and other B-Schools related to it.

- IESE (Instituto de Estudios Superiores de Empresa): Institute for Higher Business Studies, founded in 1958 in Barcelona, with a campus in Madrid and linked to the Univ. Navarra -of Opus Dei.

- ESCP-Madrid (École Supérieure de Commerce de Paris): its French parent company is one of the oldest, established in 1819. Its headquarters in Madrid date from 1988, linked to the Univ. Carlos III.

Source: own elaboration based in ENQA, CHEA, BAC, ANECA, ESADE, IE, IESE, ESCP (2020). 
In the Statement on the Modernization Agenda for Higher Education of the European Quality Assurance Register for Higher Education (EQAR, 2011), EQAR indicates that quality assurance helps to address some of the challenges that higher education in Europe faces: promoting mobility, supporting diversity, and ensuring accountability. Furthermore, the set of entrepreneurship, talent \& happiness management means adapting the curricula and proposing individualized educational paths to each profile in the processes of teaching and learning (Ferreira, Vidal \& Vieira, 2014; Salaburu, Ginés Mora \& Haug, 2011). However, there is a current risk for all this success: the Spanish B-Schools paradox. The secret of the Spanish B-Schools achievement was, precisely, their creativity, international projection, and the effort to get as many accreditations as possible. However, in recent years this triumph is at risk, and they are losing competitiveness, leadership, and positions in rankings, as shown in Table 2.

Table 2. Development of Spanish B-Schools in European rankings (2018-20)

\begin{tabular}{lccc}
\hline Spanish B-Schools & Ranking 2018 & Ranking 2019 & Ranking 2020 \\
\hline IESE & 11 & 7 & 4 \\
IE & 5 & 4 & 5 \\
ESADE & 7 & 6 & 8 \\
\hline
\end{tabular}

Source: own elaboration based in QS Global MBA Rankings: Europe (2020),

The more certifications accumulated by the B-Schools, the more they find contradictions among all the accreditation system and the more difficult it is to keep them and to achieve the renewal of the academic curricula needed to go through the accreditation process. As Lozano, Bofarull, Waddock \& Prat-i-Pubill (2018) argue, rankings force B-Schools to increasingly follow similar curricula and strategic approaches, creating an "iron cage" that influences the nature, quality, and pedagogies of what is taught, particularly for the striving B-Schools that wish to join the ranks of highly rated ones. One hypothesis of this paper is that the procedures of the Spanish Agency of Certification (ANECA) brings B-Schools closer to traditional Schools of Economics and Business at universities (and to the scholar mainstream in a welfare state economy), removing them from their link with companies and market demands (more pragmatic and closer to digital economy). State universities tend to be extremely cautious with university-business cooperation and they distrust business engagement in the design and delivery of the curricula and when meeting industry needs (Plewa, Galán-Muros \& Davey, 2015).

In view of this panorama, this article makes a historical balance of the polarized system of B-Schools vs. Schools of Economics and Business at universities in Spain, which are two complementary models mixed today. It addresses the current confusion created by the accreditation system, and it describes how and why the B-Schools are losing competitiveness ${ }^{2}$. As Ozbugday (2019) shows, quality certification does not have any positive effect on total factor productivity in general. As we will see, neither is business education positively affected by accreditations. Universities that obtain high accreditations are less inclined to innovate (e.g. they are overloaded with red tape). Actually, we may consider the accreditation system as responsible for the lack of innovation in B-Schools; when a lot of money is spent to get the accreditations, you tend to disregard the need to innovate, and then you may lose your advantage with competitors. At least in Spain, more efforts are made to get the accreditations than to improve the programs in digital economy and its wellbeing economics (the new stage of digital economy, beyond the gig phase, Sánchez-Bayón, 2019a, 2019b, 2020a, 2020b).

\footnotetext{
2 The experience of the authors in accreditation process is also backed up by the fact that the authors have served as Vice-deans for Business Schools (e.g. ISEMCO, CEDEU) and Schools of Economics and Business at universities (e.g. UCJC, UCM).
} 
The methodology applied in this paper is the usual for Institutional Economics, critical of public choice (Buchanan \& Tullock, 1962), mixed with some elements from the Austrian School of Economics, as we detect some cycles and phases in the dynamic process, and we use the techniques of inductive essentialism (Menger, 1871). The holistic approach of Global Economics \& Cross-Cultural Economics, promoted with the new hermeneutic turn by the Sweetwater Economic Schools and B-Schools, is also used -qualitative techniques- (Sánchez-Bayón, 2020b). As regards the sources used, they are secondary, as the information has been drawn from the B-Schools and the institutions which are part of the accreditation system.

This article, then, first presents a historical review of Spanish higher educational structure in Business Studies. Then, we will look at the globalization framework and the boom of Spanish B-Schools within the Spanish educational system background. The third part is a discussion about the Spanish $B$-Schools paradox that jeopardizes self-control and competitiveness in the current transitional period regarding wellbeing economics. After, we will offer an overview of the risks and some solutions (e.g. to get back to the professional intensive education within the set of entrepreneurship, talent \& happiness management). Finally, the conclusions try to give some guidance for the future which implies choosing between reviewing the accreditation system vs exploring the emergence of the low-cost digital B-Schools network.

\section{Historical review of Spanish education in business studies}

This historical and comparative overview will demonstrate that B-Schools and Schools of Economics \& Business at universities are two different institutions, with a different mission, vision, and values. So, there is a risk for both institutions (and for the system itself) when their accreditation model mixes. In particular, the domestic model of ANECA seems to be in favour of the academic paradigm and is against the entrepreneurship model (Sánchez-Bayón, 2020b).

Then, we need to show how a dual system developed in business education in Spain, with very polarized managerial cultures and results. On the one hand, the welfare state economy was the basis for the Schools of Commerce and the Schools of Economics \& Business (at universities); on the other hand, the market created the B-Schools. The former, the State education, tried to promote mass education for all. Professors used universities as a platform to gain social recognition and become politicians or ministers of the nation. The latter, the B-Schools, were part of an elite education of internationalized technocrats that influenced economics and took part on the boards of administration of large firms.

However, let us have a look at the first part of this dual system. Schools of Commerce were the initial institutions created in Spain to train merchants in the functioning of the markets. They emerged in the sixteenth century when there was no theoretical compendium of economic theories, and business and economics education was purely pragmatic. Informal schools emerged as a result of the growth of production and commercial expansion and the need of merchant's guilds to keep accounting books. The commitment to establish homogeneous accounting practices in the national scenario began with the opening trade and commerce legislation that dates back to the Ordinances of Bilbao in 1549 (Fernández Aguado, 1997).

The Aula do Comércio in Lisbon has been considered the first institution in the World to specialize in the teaching of accounting in 1759 but it was a state School of Business with the objective of spreading the word of English mercantilism (Redlich, 1957; Rodrigues \& Craig 2004; Rodrigues, Craig \& Gomes, 2007; Rodrigues, Gomes \& Craig, 2004). It provided a model for development of similar governmentsponsored schools across Europe. It closed in 1844.

In Spain, the 18th century saw an emergence of institutions for teaching commercial arts. Three port cities led the process of creating Colleges for teaching them: Caddis, Bilbao and Barcelona, each one at 
one end of the national geography. The School of Caddis, created in 1799 , was similar in nature to the Aula do Comércio in Lisbon. Then, it was not until 1815 that a commercial chair of Antonio Ala was created. Spanish 19th century development is made evident in the fact that in Alicante an institution for trade and commerce studies was created in 1816 (integrated in the Provincial Institute in 1854). In the legislative swings of the nineteenth century, on January 2nd, 1819, the opening of a centre for trade studies in Barcelona took place, which, in 1835, was named School of Commerce (Escuela de Comercio) for the first time. In Bilbao, trade and commerce studies also began in 1819 directed by Alberto Lista. Commercial studies began in Malaga in the 1824-1825 academic year (Fernandez Aguado, 1997).

The Schools of Commerce go hand in hand with legislation on trade and commerce. In 1821, the General Regulation of Public Instruction cites the teachings of Commerce along with those of Medicine, Surgery, Pharmacy, Veterinary, Agriculture, Music, Astronomy, and Navigation. It established the framework for the institution of Schools of Trade in Madrid, Caddis, Malaga, Alicante, Barcelona, Corunna, Bilbao, and Santander.

The School of Commerce of Madrid was inaugurated on May 30th, 1828 and, in October, the Regulations were published with the subjects of the curriculum: commercial arithmetic and bookkeeping that included accounting and commercial and administrative corporate names, changes, arbitrations, insurance, weights and national and foreign measures. It also included foreign languages (French and English,) history of commerce, commercial geography, legislation and commercial jurisprudence and studies of manufactured raw materials (Gallego \& Trincado, 2019). In 1829, the Commercial Code included the obligation to keep accounting books for merchants. In the Public Instruction Plan of 1836, the Special Schools of Commerce were created together with the Schools of Engineering in Public Works (Roads, Canals and Ports), Mining Engineering, Agriculture and Fine Arts and Crafts. In 1847, the Royal Decree of October 7th included trade studies in the general budgets of the state. This is a key date for the extension of the official teachings to Alicante, Barcelona, Baleares, Bilbao, Caddis, Canary Islands, Corunna, Lugo, Santander, Valencia and Madrid.

After, the origins of Political Economy as an academic subject depended on these Schools of Commerce, but also in other civic institutions (Fuentes Quintana, 1999; Gallego \& Trincado, 2019; Menéndez Blanco, Alonso González \& Moreno Gallego, 2016). The first Chair of Trade and Civil Economy was created in Spain in 1784 by the Aragonese Real Society of Friends of the Country in Saragossa (Sánchez Hormigo, Malo Guillén \& Blanco Domingo, 2003). Dates are like those in Europe, the first Chair of political economy being established in 1754 at the University of Naples in Italy with Antonio Genovesi as tenured professor (see Chisholm, 1911). Then in 1763 Joseph von Sonnenfels was appointed a Political Economy chair at the University of Vienna (Khavanova, 2017) and Thomas Robert Malthus became England's first professor of political economy at the East India Company College in 1805 (Coleman, 1996; Tribe, 1995).

In Spain, the more academic studies of Political Economy were introduced in the study plans of Law Schools in 1807. It appears simultaneously in Faculties considered "minor ones", as it was Philosophy for secondary education, and in the "major ones", as Laws and Jurisprudence in higher education. The subject was named Elements of Political Economy and Statistics (Perdices de Blas \& Reeder, 2003). In 1814 another chair was created in Barcelona held by Eudaldo Jaumeandreu and on May 8th of 1815 the Real Sociedad Económica de Amigos del País of Madrid opened a Chair of Political Economy. However, as Lluch \& Almenar (1999) state, it was not until the revolution of 1848 that Political Economy became established in Spain as part of university education.

In 1845, the General Plan of Studies called Plan Pidal strengthened the state monopoly of higher education -as education was considered to be part of State competences-including trade and commerce studies for the development of professional careers (Fernández Aguado, 1997). It was in 1845 when the first Chair of Political Economy was created in the School of Jurisprudence. Pidal limited the freedom of choice for textbooks to a list that had to be approved every three years. The first list was published in 
the Royal Order of September 1, 1846 by the Public Instruction Board (Consejo de Instrucción Pública). A list for teaching Political Economy in the School of Philosophy went with another list for the School of Jurisprudence. When books were considered unavailable or suitable, the list of books changed (Martín Rodríguez, 1989). So, these lists were a source of exchange of favours and political privileges. For instance, Valle, who appears on the first list, was also a member of the Books Committee and of the Consejo de Instrucción Pública (Almenar, 2012). Translators of books in the list were sometimes friends of the ruling class (Hernández Andreu \& Trincado, 2019). The Royal decree of October 12th, 1850 reduced the list of compulsory textbooks to three: "Curso" by Valle, "Tratado" by Colmeiro and "Elementos" by Joseph Garnier (see Lluch \& Almenar, 1999). Each professor had to choose one of those books, and successive lists would confirm the same texts, such as those of September 15th, 1852, September 18th, 1853, January 13th, 1854, and November 1st, 1855. These three authors were also repeatedly found on the lists until 1867.

On October 7th, 1847, a Royal Decree authorized the payment of the teachings of the established Trade Boards, which were charged to the general budget of the State. As of 1848, the Schools of Commerce happened to depend directly on the State: Alicante, Barcelona, Balearic Islands, Bilbao, Caddis, Canary Islands, Corunna, Lugo, Madrid, Santander, and Valencia (Fernández Aguado, 1997). The list of compulsory books was extended to the Schools of Commerce in 1861. As we see, boards and political institutions had more power in curricula of institutionalized education than professors themselves.

The Royal decree of 1845 proposed a new education model, which was consolidated by the Moyano Act of 1857 (Sánchez-Bayón, 2010). This plan meant the centralization of the Spanish university system and the predominance of the University of Madrid over others since it was the only one that could grant doctorates and give doctoral courses. During the twentieth century, this predominance lead to the emergence of the first School of Political and Economic Science in the Central University of Madrid in 1944, in 1953 called the School of Political, Economic and Commercial Science. When the General Act of Education of 1970 was passed, this university was renamed Complutense University of Madrid (Fuentes Quintana \& Serrano Sanz, 2004; Sánchez Lissen, 2007). Little after, in 1971, the School of Political, Economic and Commercial Science split in a School of Political and Sociological Sciences and a School of Economics and Business (Gutiérrez, Trincado \& Perdices de Blas, 2015). Then, in the Franco Regime, many economists combined positions of responsibility of management with their work as professors in this, and other, state universities. It is precisely this group who made the decisions that Economic Policy be related to economic knowledge in the opening of the economy of 1959 (Perdices de Blas \& Reeder, 2003). However, at the same time, it implied the construction of a corporate university, based on some tribal behaviors and culture (Trincado, 2007).

The General Act on Education of 1970 put the Faculties or Schools, not Departments, in charge of education. In this sense, it privileged university politics, unlike what happened in other countries where university education was organized in departments (which makes research more important and faculties depend on research funds, as in USA), or higher education organized as colleges (as in Oxford and Cambridge) where quality depends more on the reputation of graduate students (Berger \& Milem, 2000; Birbaum, 1988; Gieger, 1986; Kerr, 1963; Millet, 1984). Another option is management by results, typical of Finish universities (Kuoppala, 2006).

However, after Franco's death and the establishment of democracy, the University Act of 1983 positioned Spain on a hybrid faculty-department system. There was a shift from the chairs as platforms to exercise power, to professorships based on excellence and professional abilities, democratic management, and quality assessment (Gewerc, 2001). This organizational change tried to make university less ideological and more devoted to research and teaching. However, these objectives have not yet been fully achieved and some old structures still remain (Almarcha Barbado, González Jorge \& González Rodríguez, 1994). Even now, University has some of its old rites of passage, acting as a specific ritual tribe (Bourdieu, 1985; Nieto, 1984). The LOU (the Spanish University System Act of 2001) 
designed self-management of universities and engaged Autonomous communities in University financing, besides introducing external rules such as the ANECA to assess universities and professors. Study plans are not modified due to specialization reasons, students' needs or quality achievement requirement, but to internal disputes, pressure groups and personal loyalties. Besides, the volume of university students depends more on the age of the university than on assessment standards. The oldest universities in Spain are also the largest; according to de Miguel \& Sarabia (2003) and the European University Association (EUA, 2003) the correlation coefficient between seniority and size was 0.53 in 2003. Old universities have had more time to create different degrees and they have had time to accumulate more books, correlating with the size of their libraries (correlation 0.72). Besides, old universities are better known, but they are also more crowded (Trincado, 2007). In this context, abundant regulations are senseless paperwork that do not affect quality standards (Dill, 1995; Hill, 1995; Gatfield, Barker \& Graham, 1999; Wagner, 2005).

\section{The boom of Spanish B-Schools}

In Spain, since 1916, the Universidad Comercial de Deusto was a reference for private management education. According to Sanz (2016), Deusto led the management and business administration education and teaching by printing a particular stamp on its graduates: the values of the Compañía de Jesús (the Jesuits). At first, private business education was considered a way of instilling ethics in management and the market (Alcañiz, García-Feijoo \& Eizaguirre, 2019; Lozano, 2011) but the flourishing of private B-Schools (Escuelas de Negocios) began with the Spanish economic boom in the 60 s, after the National Plan of Economic Stabilization of 1959 (Fusi, 1985). This plan was possible thanks to two changes in the 1950s:

a) The external change: the international blockade cessation and the opening of borders, allowing access for migrant workers, tourists, foreign companies, etc.

b) The internal change: the development of B-Schools in two different branches; on the one hand, the religious set of schools (most of them Jesuits, e.g. ICADE, ETEA, ESADE); on the other hand, the State set of schools (e.g. EOI). In some of these B-Schools technocrats were formed to replace the Falangist and national-unionism.

Economists from state universities were the main political promoters of the Stabilization Plan -the more relevant being Joan Sardá and Fuentes Quintana, both professors from the University of Madrid (Sánchez Lissen \& Sanz, 2015). They had political contacts with the relevant ministers of the moment, such as Alberto Ullastres and Navarro Rubio, also professors at the Universidad of Madrid. B-Schools emerged with eyes on international markets (Puig, 2008). B-Schools were successful because they had a differential factor to the Schools of Economics and Business: B-Schools were professionalizing and very connected with companies and their needs. The employment opportunities thanks to the ex-alumni contacts were also part of the post-graduate facilities provided by B-Schools.

ICADE (Spanish acronym for Catholic Institute of Business Administration in English) was created in 1956 from a Seminar in Comillas (Cantabria) for the education of business executives. At first limited to the MBA studies, in 1960, it merged with ICAI (engineering studies), creating the star project of ICADE: the double bachelor's degree in Economics and Business and Law. In 1969, ICADE moved to Madrid. IESE was founded in 1958 in Barcelona as an initiative of the Opus Dei, a personal prelature of the Catholic Church. In 1963 it formed an alliance with the Harvard Business School (HBS) and launched the first two-year MBA programme in Europe. IESE now has campuses in Barcelona, Madrid, Munich, New York, and São Paulo. It has equipped its professors with an international mindset (López \& Pampliega, 1997). ESADE (Escola Superior d'Administració i Direcció d'Empreses) was also created in 1958 as a 
private Jesuit educational institution in Barcelona. ESADE runs two schools at the university, ESADE BSchool and ESADE Law School, as well as a language centre, the ESADE Executive Language Center. The strategy of internationalization was also central from the onset In 1964, the MBA program was created.

The boom of B-Schools also meant the development of human capital to lead the national companies -e.g. Telefónica, Iberia, Repsol, RENFE- (Carreras \& Tafunell, 2005), which improved the welfare state economy (Sánchez-Bayón, 2017, 2019a, 2019b). Of course, in that period, there were many business and management international transplants, but in Spain it was instilled with a special style ("Spain is different", a sentence made popular by Manuel Fraga, the Minister of Information and Tourism, 1962-1969).

With the industrializing process and the arrival of the great modern enterprise, managerial capitalism made its way, with the "Americanization" of management (Fernández Pérez \& Puig, 2009; Kipping \& Puig, 2003; Puig, 2003). The openness to American aid also led to a modernization of the entrepreneurial elites (Carreras \& Tafunell, 1993). However, American professionals who contributed to the first exchange programmes observed that the selection for management positions in Europe responded to a "sponsored mobility", according to a traditional and collectivist attitude that gave priority to kinship and social networks, in contrast to the US where they selected individuals to a greater extent based on meritocratic factors, within a "contest mobility" (Byrkjeflot, 2000).

In Spain, initial capital needs came historically more from self-financing (own or family) or marriage, than from banks or capital markets (Díaz Morlán, 2013). In some way, this process goes hand in hand with what happened in the state universities with political advisers and ministries: it is the so-called revolving-doors phenomenon that created a political and entrepreneurial oligarchy or establishment (Farinós Viñas, García Martín, Herrero Piqueras \& Ibáñez Escribano, 2016; Jones, 2015; Rizo \& Stella, 2015). This has been critically called clientelism capitalism (Naredo, 2019).

Although the formal educational level of Spanish businessmen did not diverge too much from that of their foreign counterparts (Tortella, Quiroga \& Moral-Arce, 2011), formal training of directives was scarce. However, there were exceptions: the IESE had emerged as an important extractive institution for the Spanish management elite and led to the existence of cross advisers between Schools of Business enterprises (Chirosa-Cañavate, Rubio-Mondéjar \& Garrués-Ururzun, 2020). The Instituto de Empresa (IE) was founded in 1973 in Madrid by three entrepreneurs (one of them, the Marquess Diego del Alcázar Silvela) with the goal of fostering an entrepreneurial environment. They promoted international collaborations such as a dual MBA with Brown University and an Asian-focused programme run with Singapore Management University.

\section{Globalization and B-Schools brand by accreditation}

With the introduction of democracy, above all in the late twentieth century, there has been a process of homologation with Europe and of globalization in higher education standards. Notwithstanding, there are two options for the quality assessment of Business Schools: a model based on external assessment, such as the accreditation system (international accreditation, e.g. EQUIS, domestic accreditation, e.g. ANECA) or a flexible model based on the alumni pride or the power design. Accreditations may also be private or part of a government accreditation system. In general, the accreditation system is expensive for B-Schools, with the high cost of information and opportunity cost, but also because it is extremely expensive to get and retain the accreditation. It is very bureaucratic, less agile for changes and challenges in the process than a more flexible model based on market signs. Without an accreditation system, students would have to recur to alternatives to obtain information -the rise of international institutions may have been an optimal solution to the information problem.

In the context of the Bologna agreement signed in 1999, different accreditation agencies have been created in Europe to avoid corporatism and reduce the information costs for students when assessing the quality of business studies. In Spain, ANECA, whose acronym (in Spanish) stands for National Agency 
for Quality Assessment and Accreditation, tends to privilege the traditional model of the Faculties of Business. ANECA is a foundation created by the Spanish Government in 2002 according to the Public Law of Universities of 2001 (modified in 2007). It has the status of independent agency in the Spanish Public Administration, linked with other European agencies, because it is a member of the European Consortium for Accreditation in Higher Education (as part of the European Higher Education Area).

ANECA's mission is the verification of the programs which are expected to be taught in all the country. To complete it, ANECA makes a periodical call for panels of experts (assessors) among the scholars at the universities. However, almost $100 \%$ of them come from public universities and public research centres, e.g. IIE, CSIC. Only a few come from private universities, but none come from the B-Schools (ANECA, 2017). Usually, they are advisors without real business experience and, as we have seen in the historical construction of university institutions, they have usually been hired under a corporate system, with its traditional passage rituals. According to ANECA's criteria, at least $50 \%$ of the professors of an accredited institution need to be scholars (teachers with a $\mathrm{PhD}$ and with the professor accreditation). So, they are not businessmen but people who have obtained "sexenios" (six-yearly research assessment), traditionally not easily held by business professors. As Cancelo \& Bastida (2013) say, these six year assessments were initially designed as a bonus to promote research among the Spanish university community but now they have lost their character of productivity bonus and have become a requirement for pursuing a university career, going against businessmen trying to teach what they have learned from their activity.

International accreditations by AMBA, EQUIS or AACSB do not face the same problems as ANECA. For example, their evaluation system does not come from public regulation (it is an agreement among members); the evaluators also have some business expertise (or at least, they use management techniques taught in the B-Schools). With globalization, the B-Schools had the chance to offer their programmes to the whole world, and for this reason, the international accreditation system looked like a good idea to get fame and reputation on the global map (just 90 BS in the world have it). This is assumed to be a system of excellence, evaluated by non-governmental organizations, which operate as rating agencies.

The B-Schools managers considered that having these accreditations was a way to create international links and improve the prestige of the School, differentiating their products from state universities.

In this sense, accreditations were part of their plan to innovate and distinguish their product. These accreditations were not compulsory and, so, they had freedom to choose. However, little by little, this also began to change: some international accreditation institutions are moving from rating agencies to normalized collaborators of the European system of convergence of quality assessment. At the end of the day, some of them have also become part of the public sector. For instance, EQUIS depends on a foundation that receives funds from the European Union.

How does this international accreditation process work in higher education institutions? In the following figure (Table 3), there is a comparative explanation between the 3 principal accreditations (AMBA, AACSB \& EQUIS), which comprises the triple crown (the superior recognition worldwide). It shows the high cost of the accreditations system, which is around 30,000 euros to get each accreditation and close to 4,000 euros for each annual fee.

As shown in Table 3, the triple crown branding is extremely expensive in terms of money, time, and bureaucracy. Besides, it renders B-Schools unable to change their programmes by themselves. To get all those accreditations, every B-School must spend almost $\$ 100,000$ and 2 years of red-tape; it is also necessary to pay an annual membership fee of around $\$ 15,000$ (for all of them). In addition, each year, it is compulsory to submit a complete report to each accreditation system. More troublesome is the EQUIS system, which requires reaccreditation every three years. In the case of the Business Schools in Spain, and their successful international position with 4 of them in the European top 10 and with triple crown (something that just 7 countries currently have), the situation is beginning to be quite dangerous. 
Table 3. The cost of the triple-crown (accreditation process fees in 2019)

\begin{tabular}{|c|c|c|c|}
\hline & $\begin{array}{l}\text { AACSB International } \\
\text { (Priv. assoc.: } \\
\text { Tampa, 1916) }\end{array}$ & $\begin{array}{l}\text { AMBA } \\
\text { (Priv. assoc.: } \\
\text { London, 1967) }\end{array}$ & $\begin{array}{l}\text { EQUIS } \\
\text { (Priv. system by EFMD: } \\
\text { Brussels,1997) }\end{array}$ \\
\hline Accred. Fees & $\begin{array}{l}\text { Eligibility application fee: } \$ 2,000 \\
\text { Process acceptance fee: } \$ 6,500 \\
\text { Initial accreditation fee: } \$ 5,950 \\
\text { Accreditation visit application } \\
\text { fee: } \$ 15,000 \\
\text { Deferral visit fee: } \$ 5,500\end{array}$ & $\begin{array}{l}\text { Registration fee: } £ 2,000 \\
\text { Pre-assessment fee: } £ 5,000 \\
\text { Assessment visit fee: } \\
£ 15,000\end{array}$ & $\begin{array}{l}\text { Application fee: } € 9,750 \\
\text { Review fee: } € 16,250 \\
\text { Annual accreditation fee: } \\
€ 3,250\end{array}$ \\
\hline Total & $\$ 34,950$ & $£ 22,000(\$ 28,600)$ & $€ 29,250(\$ 33,930)$ \\
\hline Annual fee & $\$ 5,950$ & $£ 4,500$ & $€ 3,250$ \\
\hline BS accred. & $\begin{array}{l}\text { 836BS in } 52 \text { countries (only } \\
\text { AACSB: } 657 \text { BS, } 68 \% \text { USA) }\end{array}$ & $\begin{array}{l}265 \text { BS in } 54 \text { countries } \\
\text { (only AMBA: } 113, \text { global) }\end{array}$ & $\begin{array}{l}176 \text { BS in } 41 \text { countries } \\
\text { (only EQUIS: } 19,69 \% \\
\text { Europe) }\end{array}$ \\
\hline Benefit & $\begin{array}{l}\text { Not official (denied by CHEA), but it } \\
\text { recognizes a standard distinction for } \\
\text { BS \& all programs }\end{array}$ & $\begin{array}{l}\text { Not official, but it } \\
\text { recognizes a standard } \\
\text { distinction for post- } \\
\text { graduate programs }\end{array}$ & $\begin{array}{l}\text { Almost official (EU } \\
\text { support); it recognizes } \\
\text { a quality distinction for } \\
\text { BS }\end{array}$ \\
\hline
\end{tabular}

Source: own elaboration based in MBA Today (2019) and QS Global MBA Rankings: Europe. (2020).

If the B-Schools pay for these international accreditations, it is because they think that the profit compensates the price but now, the existence of a government accreditation system with a rigid institution such as ANECA has created distortions in the education system. In the 2000s, the control of ANECA increased but the government system of accreditation compels universities to research more than teach (Fernández-Esquinas, 2003; Gewerc, 2001). The situation affects the accreditation standards of the B-Schools that depend more and more on the risks and opportunities of globalization. Finally, Business Schools controlled by religious institutions renounced their origins as independent B-Schools to become private universities (most of them switched in the 90s, and currently ETEA, ESIC or Villanueva have also switched).

However, many B-Schools have flourished during recent decades, especially in Madrid. In Table 4 the different B-Schools under the control of ANECA are classified by cities (there are many more B-Schools, though, e.g. just in Madrid, according to the Spanish B-Schools Assoc. -AEEN- there are more than 50 B-Schools members).

The necessary validation of the Spanish agency (ANECA) prevents the progress of professional training to lead the transition to digital economy (Sánchez-Bayón, 2014). The curricula renewal of Spanish B-Schools needs to be addressed to the digital transition, as in Andreu \& Sánchez-Bayón (2019) or González \& Sánchez-Bayón (2019) so how is it possible that the creative and successful Spanish B-Schools take so much time to modify their official curricula? In the last decade (2010s), many B-Schools did not include-as they should have, beyond the soft-skills- the three hot-topics for digital economy (in gig phase, Sánchez-Bayón, 2019a, 2020b) in their programmes. The B-Schools had sectorial and instrumental courses in the digital transition, like Business Intel or Digital Marketing (with many traditional approaches and subjects) but few of them were specialized in non-official short courses on the new paradigm that is proper to them, entrepreneurship, talent and happiness management that 
study wellbeing and happiness, rather than being based on the old welfare state economy paradigm. In the official programmes (like MBA), there were some specific subjects based on this paradigm, but they were treated as soft-skills, without real professional contents (we have checked this in the RUCT -Spanish acronym for Public Register of Universities, Centres and Programs).

Table 4. List of main Spanish BS into the official educational system (under ANECA control)

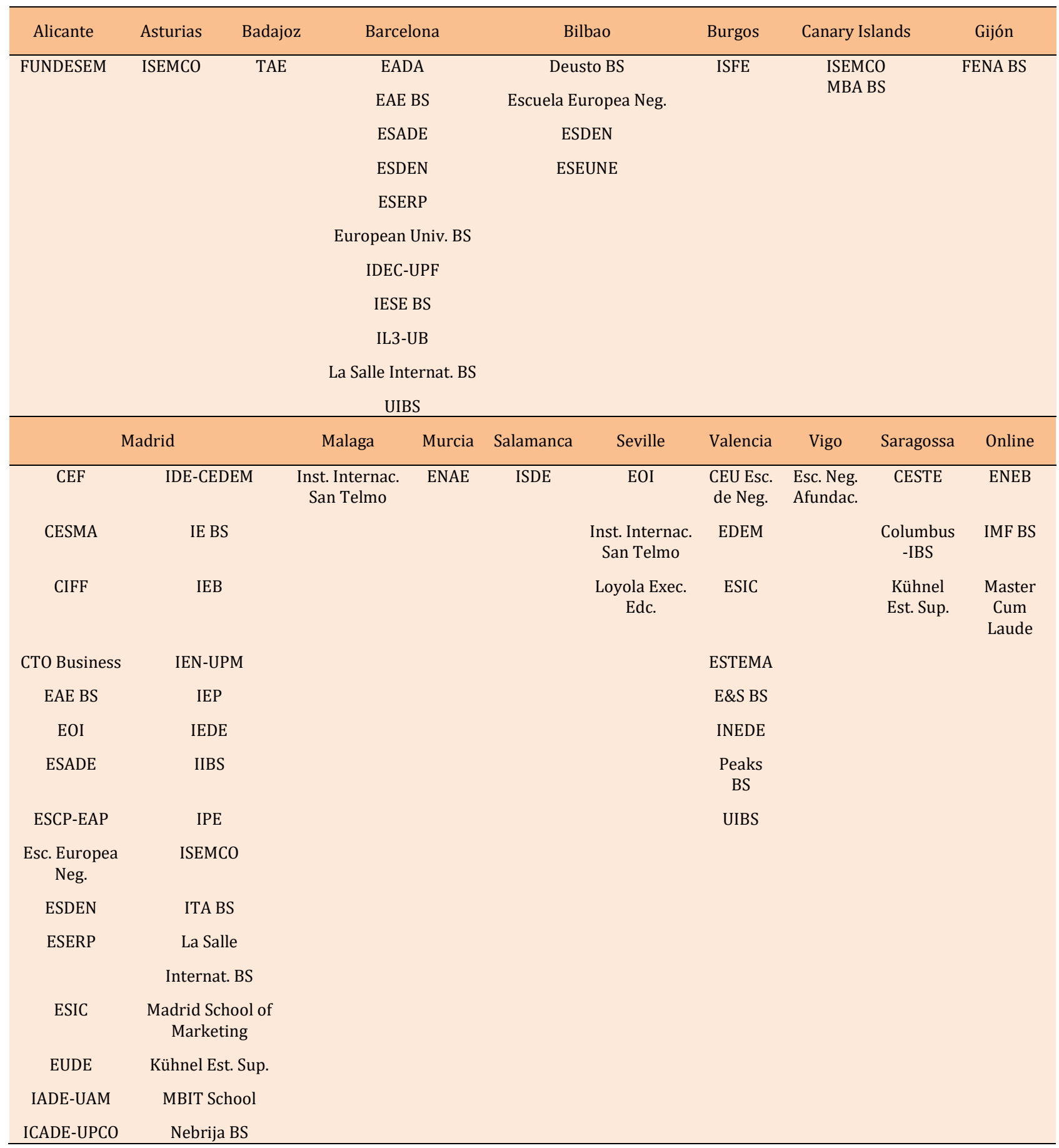

Source: Own elaboration (based on ANECA resources). 
Besides the fact that B-School curricula is now less flexible to market needs, the paradox is that the more international accreditations are obtained, the more difficult it is to keep them. In part, this is due to the contradictions between the systems and agencies: e.g. the AACSB reinforces the engagement and procedures, AMBA the standardizations and measures, ANECA the collection of evidence for future verifications, and all of them have their own evaluation systems with different scores and goal preferences. Bureaucracy also tries to carry out any change implying loss of creativity. Business Schools use their creativity to obtain accreditations, but, as we have commented, they do not show creativity in new programs, approaches, theories, or practices. In the same vein, Gosling \& Mintzberg (2004) argue that because students spend so much time developing quick responses to packaged versions of business problems, they do not learn enough about real world experiences.

\section{Bureaucracy versus technovation}

As we have seen, the original focus of B-Schools was professionalization and a direct relation with markets and enterprises. However, in the course of time, the Spanish B-Schools have moved closer to universities (or they have become one). A traditional advantage of B-Schools was less bureaucracy and more open proposals for innovative programs related to the changes in the economic and business reality. However, that is no longer the case and has the disadvantage of being more expensive than state universities, the price of an MBA in IES being 89.950€ and in the IE B-School 72.200 €, while an MBA in a state university can cost $4.500 €$. This price difference was justified by the innovation and professionalization of the B-Schools programmes, but with the domestic accreditation system, this does not apply. This cost is high (the triple crown costs almost $\$ 100,000$ and a membership of $\$ 15,000$ per year), affecting the prices of the programs: high academic fees are maintained as fewer students enrol.

Looking at the IE case (as one of the B-Schools with the triple crown), where official programmes are offered with a high tuition fee but where the possibility of several editions per year no longer exist the groups being smaller each time (which is one of the ANECA limitations: a maximum quota of students per edition). How can the expensive accreditation system be suitable if student enrollment is lesser? Until now, IE has continued having profits of 150 million euros per year, but it is thanks to the business diversification and, also, because the accreditations system peak is well-known (SABI, 2020). For example, IE established its spin-off, IEBS digital school, trying to deal with a new competition with the emergence model of low-cost digital B-Schools network (e.g. IronHack, The Code, The Power $M B A)$.

However, the problem of mixing B-Schools (practice oriented) with Schools of Business at universities (theory oriented), and to become too scientific and disconnected from the business-world, is common in the Western countries. But it is more intensive in Spain. Possibly, the compliance regulation and the role of the ANECA, which demands to the B-Schools fewer professional requirements and more academic standards, is part of the problem. To pass a new official program, it must be supported by a university, and more than the $50 \%$ of the faculty requires a $\mathrm{PhD}$ dissertation and some other accreditations, so the participation of professional people is restricted. For this reason, a Copernican revolution (thanks to the current hermeneutic turn with the Nobel Prize in Economics, mixed behavior, development \& cultural Economics, from Hayek and Simon to Williamson, Ostrom or Thaler (Sánchez-Bayón, 2019a, 2020b), it may be needed so as to come back to the original professional role of the B-Schools. The B-Schools leadership with programs that teach the set of entrepreneurship, talent and happiness management is needed, not just as soft-skills, but also as hard-knowledge, attitudes and practices oriented to results. This set includes organization oriented to results and people (Seligman, 2011), with a real culture of engagement and entrepreneurship of their collaborators (Fernández, 2015). 
Many authors acknowledge that globalization has been a transitional period between a time dominated by the nation-State and its rigid welfare state economy, bureaucratized, hierarchical and constrained by scarcity, to another of the global village and its flexible digital economy (Bordo, Taylor \& Williamson, 2003; Klein, \& Pritchard, 2018)3. This transition is the breeding ground for crises and uncertainty, hence the classification of liquid, diffuse or risk companies that has resulted in a great change of social game: new players, rules and board (Sánchez-Bayón, 2018; Valero \& Sánchez-Bayón, 2018).

At a macro level, the country-brand ("Marca-España" in this case -today "España Global”), it needs to be promoted for the B-Schools to achieve notoriety and gain reputation, which makes Spain an attractive investment, bringing tourism, avoiding brain drain, etc. (Sánchez Guitián \& Zunzarren, 2013). At the micro level, a general accepted way for achieving reputation was that of international accreditations (Kaplan, 2014) but, nowadays, the state accreditation prevents this reputation from being effective. Until the late twentieth century, welfare state economy paradigm was under the metaphor of production chain and then, the mentioned set (of entrepreneurship, talent \& happiness management) was unnecessary. The B-Schools trained in an operational and bureaucratic way, to be a repetitive technician and under supervision. B-Schools focused on training managers and the star program was the MBA. Now, in the digital economy, the B-Schools must prepare students in entrepreneurship and creativity, to be talented professionals, and able to get through to other professionals. In short, they need to have independent market-oriented ideas, just the opposite to the dependent and protected education institutions where they are trained.

\section{Conclusions}

This article compares the evolution of the Spanish Schools of Business at universities and the B-Schools, also divided between academic and professional institutions, with civil and religious origins. It shows how a dual education system was consolidated, until the current hybridization related to the Spanish B-Schools paradox.

The article alludes to several present and potential future risks for Spanish B-Schools if they continue taking part in the accreditation system. As the Spanish B-School paradox proves, the more international accreditations the Spanish B-Schools get, the more difficult it is to keep them, because of the red-tape and the contradictions among the verification systems. They must dedicate a long time and sources to maintain the accreditations. The cost for the B-Schools is extremely high (cost of opportunity, marginal costs, etc.). However, the biggest contradiction of the accreditation system is the official Spanish agency of verification (ANECA), because the system was intended for universities with theory focus and scholars to confirm the welfare state economy paradigm.

The B-Schools need to go back to the professionalization focus, with businessmen (as instructors) and innovative proposals in digital economy, specially, for the transition to the new level: wellbeing economics. Those new proposals, directly related to the digital economy and market and business demands, need an agile renewal of academic curricula, so as to introduce the set of entrepreneurship, talent \& happiness management for the wellbeing economics paradigm to flourish in a global digital economy. Today, the emergency is to recover the professionalization of the B-Schools to train in leadership and ease the transition of the digital economy to a new level: the gig economy and well-being economics. For this reason, it is necessary to move on to an agile system, as the new generation of digital B-Schools are doing (e.g. The PowerMBA, IronHack, The Code).

\footnotetext{
3 Although some others challenge the general opinion that globalization limits the state's capacity for domestic government and argue that it can enable it as well as constrain it, and that its effects depend on the character of the country's domestic institutions (Weiss, 2003).
} 


\section{References}

Agencia Nacional de Evaluación de la Calidad y Acreditación. (2017). Paneles de expertos. Programas de evaluación. Madrid: ANECA.

Retrieved from: http://www.aneca.es/Programas-de-evaluacion/Evaluacion-de-titulos/SIC/Comisiones-yPaneles-de-expertos/SELLOS-INTERNACIONALES-DE-CALIDAD-paneles-de-expertos/Paneles-de-expertos.

Alcañiz, L., García-Feijoo M., \& Eizaguirre, A. (2019). La humanización de la actividad empresarial a través de la educación universitaria. Boletín de Estudios Económicos, 74(227), 411-436.

Retrieved from: https://dialnet.unirioja.es/servlet/articulo?codigo=7059048

Almarcha Barbado, A., González Jorge, C., \& González Rodríguez, B. (1994). Cambio y desigualdad en el profesorado universitario. REIS: Revista Española de Investigaciones Sociológicas, 66, 117-139.

Retrieved from: https://dialnet.unirioja.es/servlet/articulo?codigo $=768670$

Almenar, S. (2012). Teaching, spreading and preaching: Textbooks of political economy in Spain 1779-1936. In M. M. Augello \& M. E. L. Guidi (Eds.), The economic reader. Textbooks, manuals and the dissemination of the economic sciences during the nineteenth and early twentieth centuries (pp. 158-188). Abingdon, UK: Routledge.

Andreu, A., \& Sánchez-Bayón, A. (2019). Claves de Administración y Dirección de Empresas en la posglobalización, Madrid: Delta.

Armstrong, J. S. (1995). Business School prestige. Research versus teaching. Journal of Marketing, 59, $101-106$.

Asociación Española de Escuelas de Negocios (AEEN). https://www.aeen.org

Association of MBAs (AMBA). https://www.associationofmbas.com

Association to Advance Collegiate Schools of Business (AACSB). https://www.aacsb.edu

Berger, J. B., \& Milem, J. (2000). Organizational behavior in higher education and student outcomes. In J. C. Smart (Ed.), Higher education: Handbook of theory and research, vol. XV (pp. 268-338). New York, NY: Agathon.

Birnbaum, R. (1988). How colleges work: The cybernetics of academic organization and leadership. San Francisco, CA: Jossey-Bass.

Bordo, M. D., Taylor, A. M., \& Williamson, J. G. (Eds.). (2003). Globalization in historical perspective. Chicago: The University of Chicago Press.

Bourdieu, P. (1985). ¿Qué significa hablar? Economía de los intercambios lingüísticos. Madrid: Akal.

Buchanan, J. M., \& Tullock, G. (1962). The calculus of consent: Logical foundations of constitutional democracy. Ann Arbor, MI: University of Michigan.

Byrkjeflot, H. (2000). Management education and selection of top managers in Europe and the United States. Bergen, Norway: LOS-Senter-Rapport.

Cancelo Márquez, M. \& Bastida Domínguez, M. (2013). La evaluación de la investigación en españa: los sexenios en las áreas de economía y empresa. Ciriec-Espana, Revista de Economía Pública, Social y Cooperativa, 78, $265-292$. Retrieved from: https://www.redalyc.org/pdf/174/17429865013.pdf

Carreras, A., \& Tafunell, X. (1993). La gran empresa en España (1917-1974). Una primera aproximación. Revista de Historia Industrial, 3, 127-175.

Retrieved from: https://dialnet.unirioja.es/servlet/articulo?codigo $=2266853$

Carreras, A., \& Tafunell, X. (Coords.). (2005). Estadísticas históricas de España. Siglos XIX-XX. (2ª edición revisada y ampliada). Bilbao: Fundación BBVA. Retrieved from: https://www.fbbva.es/wp-content/uploads/2017/05/dat/DE 2006 estadisticas historicas.pdf

Council for Highher Education Accreditation. (2019). CHEA Committee on Recognition recommended that CHEA deny recognition to AACSB International. Washington, DC: CHEA.

Retrieved from: https://www.chea.org/sites/default/files/2019-03/AACSB.pdf

Chirosa-Cañavate, L., Rubio-Mondéjar, J. A., \& Garrués-Ururzun, J. (2020). Business schools and the Spanish business elite since the mid-twentieth century. Business History.

DOI: https://doi.org/10.1080/00076791.2020.1726893

Chisholm, H. (Ed.). (1911). Genovesi, Antonio. Encyclopædia Britannica, 11 (11th ed.). Cambridge, UK: Cambridge University Press. cambridge

Coleman, W. O. (1996). How theory came to English classical economics. Scottish Journal of Political Economy, 43(2), 207-228.

Retrieved from: https://onlinelibrary.wiley.com/doi/abs/10.1111/j.1467-9485.1996.tb00674.x

de Miguel, J., \& Sarabia, B. (2003). La universidad española en un mundo globalizado: los recursos. Revista Española de Investigaciones Sociológicas, 102, 207-259. DOI: http://doi.org/10.2307/40184542 
Díaz Morlán, P. (2013). Cómo han obtenido su capital inicial los empresarios británicos y españoles (c. 1800-c. 1939) Revista de Historia Industrial, 51, 19-42.

Dill, D. D. (1995). Through deming's eyes: A cross-national analysis of quality assurance policies in higher education. Quality in Higher Education, 1(2), 95-110. DOI: https://doi.org/10.1080/1353832950010202

Edhec Business School nuevamente acreditada por la AACSB por 5 años: un tributo al modelo "EDHEC for Business". Pr Newswire. (April 10, 2014). Retrieved from:

https://www.prnewswire.com/news-releases/edhec-business-school-nuevamente-acreditada-por-la-aacsbpor-5-anos-un-tributo-al-modelo-edhec-for-business-254778871.html

EQUIS. EFMD Quality Improvement Systems. https://www.efmdglobal.org/accreditations/business-schools/equis

Escuelas de negocios y competitividad. Portafolio. (Octobr 8, 2010). Retrieved from: https://www.portafolio.co/opinion/otros-columnistas/escuelas-negocios-competitividad-136066

European Quality Assurance Register for Higher Education. (2011). Statement on the modernisation Agenda for Higher Education. Brussels, Belgium: EQAR.

Retrieved from: https://www.eqar.eu/statement-on-the-european-commission-modernisation-agenda/

European University Association. (2003). The Role of the Universities in Shaping the Future of Europe. Brussels, Belgium: EUA. Retrieved from: http://www.aic.lv/ace/ace disk/Bologna/contrib/EUA/role univ.pdf

Farinós Viñas, J. E., García Martín, C. J., Herrero Piqueras, B., \& Ibáñez Escribano, A. M. (2016). Revolving doors: Are they valued in the Spanish stock market?, Academia Revista Latinoamericana de Administracion, 29(2), 147-164. DOI: https://doi.org/10.1108/ARLA-07-2015-0172.

Fernández Aguado, J. (1997). Historia de la Escuela de Comercio de Madrid. Madrid: Asociación Española de Contabilidad y Administración de Empresas (AECA).

Fernández Pérez, P., Puig, N. (2009). Global lobbies for a global economy: The creation of the Spanish Institute of Family Firms in international perspective. Business History, 51(5), 712-733. DOI: https://doi.org/10.1080/00076790903125610

Fernández, I. (2015). Felicidad organizacional. Cómo construir felicidad en el trabajo, Santiago de Chile, Chile: Ediciones B.

Fernández-Esquinas, M. (2003). From 'apprenticeship' to 'training': An empirical enquiry into the preparation of scientists in Spanish Academic Science. IESA Working Paper WP Series 05-03. Madrid: Instituto de Estudios Sociales Avanzados. Retrieved from: http://digital.csic.es/bitstream/10261/2119/1/05-03.pdf

Ferreira, C., Vidal, J., \& Vieira, M. J. (2014). Student guidance and attention to diversity in the processes of quality assurance in higher education. European Journal of Education, 49(4), 575-589. DOI: https://doi.org/10.1111/ejed.12098

Fuentes Quintana, E. (1999). La consolidación académica de la economía española. In E. Fuentes Quintana (Coord.), Economía y economistas españoles, vol. 7 (pp. 7-145). Madrid: Galaxia Gutemberg/Círculo de Lectores.

Fuentes Quintana, E., \& Serrano Sanz, J. M. (2004). El nacimiento de una profesión. In E. Fuentes Quintana (Coord.), Economía y economistas españoles, vol. 8 (pp. 7-125). Madrid: Galaxia Gutemberg/Círculo de Lectores.

Fusi, J. P. (1985). El boom económico español. Madrid: Cuadernos Historia 16.

Gallego, E., \& Trincado, E. (2019). Debates on development in the Spanish Economy, 1848-1960. In E. Trincado, A. Lazzarini \& Denis Melnik (Eds.), Ideas in the history of economic development: The case of peripheral countries. London, UK: Routledge.

Gatfield, T., Barker, M., \& Graham, P. (1999). Measuring student quality variables and the implications for management practices in higher education institutions: An Australian and international student perspective. Journal of Higher Education Policy \& Management, 21(2), 239-252.

DOI: https://doi.org/10.1080/1360080990210210

Gewerc, A. (2001). Identidad profesional y trayectoria en la universidad. Profesorado, Revista de Currículum y Formación del Profesorado, 5(2), 1-15.

Retrieved from: https://dialnet.unirioja.es/servlet/articulo?codigo $=837970$

Gieger, R. (1986). The growth of American Research Universities, 1900-1940. New York, NY: Oxford University Press.

González, E., \& Sánchez-Bayón, A. (2019). Nuevas tendencias en RR.HH. desarrollo de talento profesional. Porto, Portugal: Sindéresis.

Gosling, J., \& Mintzberg, H. (2004). The education of practicing managers. MIT Sloan Management Review, 45(4), 19-22. Retrieved from: https://sloanreview.mit.edu/article/the-education-of-practicing-managers/ 
Gutiérrez, M., Trincado, E., \& Perdices de Blas, L. (2015). Facultad de Ciencias Económicas y Empresariales. Reseña histórica. Retrieved from: https://economicasyempresariales.ucm.es/resena-historica

Hernández Andreu, J., \& Trincado, E. (2019). The Economic discourse of Joseph Garnier in Spain. History of Economic Thought and Policy, 2(2), 5-34.

Hill, F. M. (1995). Managing service quality in higher education: The role of the student as primary consumer. Quality Assurance in Education, 3(3), 10-21. DOI: https://doi.org/10.1108/09684889510093497

Hult International Business School nombrado finalista para el Premio a la Innovación MBA de la AMBA. $\mathrm{Pr}$ Newswire. (October 7, 2014). Retrieved from: https://www.prnewswire.com/news-releases/hult-international-business-school-nombrado-finalista-parael-premio-a-la-innovacion-mba-de-la-amba-278361451.html

IESE Business School obtiene acreditación AACSB Internacional. AméricaEconomía.com. (April 12, 2010). Retrieved from:

https://mba.americaeconomia.com/articulos/notas/iese-business-school-obtiene-acreditacion-aacsbinternational

Jones, O. (2015). El Establishment. Barcelona: Seix Barral.

Kaplan, A. M. (2014). European Management and European Business Schools: Insights from the history of business schools. European Management Journal, 32(4), 529-534. DOI: https://doi.org/10.1016/j.emj.2014.03.006

Kerr, C. (1963). The uses of the university. Cambridge, MA: Harvard University Press.

Khavanova, O. (2017). Joseph von Sonnenfels's Courses and the Making of the Habsburg Bureaucracy. Austrian History Yearbook, 48, 54-73. DOI: http://doi.org/10.1017/S0067237816000552

Kipping, M., \& Puig, N. (2003). Entre influencias internacionales y tradiciones nacionales: las consultoras de empresa en la España del siglo XX. Cuadernos de Economía y Empresa, 17, 105-137.

Klein, E. B., \& Pritchard, I. L. (2018). Relatedness in a global economy. London, UK: Routledge.

Kuoppala, K. (2006). Management by results at finnish universities. Journal of Higher Education Policy and Management, 27(3), 345-355. DOI: https://doi.org/10.1080/13600800500283692

Lackéus, M. (2015). Entrepreneurship in education. What, why, when, how. Brussels, Belgium: European Commission. Retrieved from: https://www.oecd.org/cfe/leed/BGP Entrepreneurship-in-Education.pdf

Levering, R. (1984). 100 best companies to work for in America. Reading, MA: Addison-Wesley.

Levering, R. (1988). A great place to work. New York, NY: Ramdom House.

Lluch, E., \& Almenar, S. (1999). Difusión e influencia de los economistas clásicos en España (1776-1870). In E. Fuentes Quintana (Coord.), Economía y economistas españoles, vol. 4 (pp. 93-170). Madrid: Galaxia Gutemberg/Círculo de Lectores.

López, T., \& Pampliega, J. (1997). La fundación del IESE (1956-1958). IESE. Revista de Antiguos Alumnos, 68, 41-44. Retrieved from:

https://www.unav.edu/web/centro-de-estudios-josemaria-escriva/bibliotecavirtual/details.vm?w=sortAuthorities $\% 3 \mathrm{~A} \% 22$ Valero+y+Vicente $\% 2 \mathrm{C}+$ Antonio $\% 22 \&$ view=global\&lang=es

Lozano, J. M. (2011). Liderazgos, no líderes. Los ejercicios espirituales y las escuelas de negocio. Revista de Fomento Social, 262, 181-218. DOI: https://doi.org/10.32418/rfs.2011.262.1864

Lozano, J., Bofarull, I., Waddock, S., \& Prat-i-Pubill, Q. (2018). Avoiding the iron cage of business school rankings. Higher Education Policy, 33(1), 135-157. DOI: https://doi.org/10.1057/s41307-018-0107-7

Martín Rodríguez, M. (1989). La institucionalización de la economía política en la universidad española (17841857). In M. Martín Rodríguez (Ed.), Elementos de economía política con aplicación particular a España. Madrid: Instituto de Estudios Fiscales.

MBA Today. (2019). Guide of triple accreditation.

Retrieved from: https://www.mba.today/guide/triple-accreditation-business-schools

Menéndez Blanco, J. M., Alonso González, L. A., \& Moreno Gallego, L. S. (2016). 0 papel da austeridade na saída da crise dos países periféricos da eurozona: unha análise desde a política económica. Revista Galega de Economía, 25(2), 5-12. Retrieved from: https://revistas.usc.gal/index.php/rge/article/view/3729

Menger, C. (1871/2020). Principios de Economía Política. 3a ed. Madrid: Unión Editorial. Retrieved from: http://www.esflspain.org.server.studentsforliberty.org/wp-content/uploads/2015/09/principios-deeconomia-politica.pdf

Millett, J. D. (1984). Conflict in higher education: State Government coordination versus institutional independence. San Francisco, CA: Jossey-Bass.

Naredo, J. (2019). Taxonomía del lucro. Madrid: Siglo XXI. 
Nieto, A. (1984). La tribu universitaria. Madrid: Tecnos.

Ozbugday, F. C. (2019). The effects of certification on total factor productivity: A propensity score matching approach. Managerial and Decision Economics, 40(1), 51-63. DOI: https://doi.org/10.1002/mde.2979

Peña, A. (2018). Las escuelas de negocios recogen la llama de la sabiduría. Actualidad Económica, 45.

Perdices de Blas, L., \& Reeder, J. (2003). Diccionario del pensamiento económico en España (1500-2000). Madrid: Síntesis.

Plewa, C., Galán-Muros, V., \& Davey, T.. (2015). Engaging business in curriculum design and delivery: A higher education institution perspective.Higher Education: The International Journal of Higher Education Research, 70(1), 35-53. DOI: https://doi.org/10.1007/s10734-014-9822-1

Puig, N. (2003). Educating Spanish managers. The United States, modernizing networks, and business schools in Spain, 1950-1975. In R. Petter Amdam, R. Kvalshaugen \& E. Larsen (Eds.), Inside the business schools: The content of European business (58-86). Oslo, Norway: Copenhagen Business School Press.

Puig, N. (2008). Business education in Spain. Business History Review, 82(2), 329-358.

QS Global MBA Rankings: Europe. (2020). Best Business Schools in Europe (2018, 19 \& 20 rankings).

Retrieved from: https://www.topmba.com/mba-rankings/europe/2020

Rizzo, S., \& Stella, G. A. (2015). La casta. De cómo los políticos se volvieron intocables. Madrid: Capitán Swing.

Redlich, F. (1957). Academic education for business. The Business History Review, 31(1), 41.

Rodrigues, L. L., \& Craig, R. (2004). English mercantilist influences on the foundation of the Portuguese School of Commerce in 1759. Atlantic Economic Journal, 32(4), 329-345.

Rodrigues, L. L., Craig, R., \& Gomes, D. (2007). State intervention in commercial education: The case of the Portuguese School of Commerce, 1759. Accounting History, 12(1), 55-84. DOI: https://doi.org/10.1177/1032373207072808

Rodrigues, L. L., Gomes, D., \& Craig, R. (2004). The Portuguese School of Commerce, 1759-1844: A reflection of the enlightenment. Accounting History, 9(3), 53-71. DOI: https://doi.org/10.1177/103237320400900304

SABI.https://www.bvdinfo.com/es-es/nuestrosproductos/datos/nacional/sabi?gclid=EAIaIQobChMI0YWp1sng6gIVU4fVCh16EgEbEAAYASAAEgJKGPD Bw $\underline{\mathrm{E}}$

Sáenz, A. (2016). La formación de directivos: el papel y la visión de la Deusto Business School (la Universidad Comercial de Deusto). Boletín de Estudios Económicos, 71(218), 239-245.

Salaburu, P., Ginés Mora, J., \& Haug, G. (2011). España y el proceso de Bolonia: un encuentro imprescindible. Madrid: Academia Europea de Ciencias y Artes. Retrieved from: http://repositori.uji.es/xmlui/handle/10234/30976

Sánchez Hormigo, A., Malo Guillén, J. L., \& Blanco Domingo, L. (2003). La Cátedra de Economía Civil y Comercio de la Real Sociedad Económica Aragonesa de Amigos del País (1784-1846). Zaragoza: Real Sociedad Económica Aragonesa de Amigos del País.

Sánchez Lissen, R. (2007), Los economistas de la Escuela de Madrid. Madrid: Instituto de Estudios Económicos/ Colegio de Economistas de Madrid.

Sánchez Lissen, R., \& Sanz, T. (2015). El Plan de Estabilización español de 1959: Juan Sardá Dexeus y la economía social de mercado. Investigaciones de Historia Económica, 11(1), 10-19.

DOI: http://doi.org/10.1016/j.ihe.2013.11.014

Sánchez Guitián, J. M., \& Zunzarren, H. (2013). ¿Cómo se gestiona una marca país? Madrid: ESIC.

Sánchez-Bayón, A. (2010). Estudios de cultura político-jurídica. Madrid: Delta.

Sánchez-Bayón, A. (2014). Innovación docente en los nuevos estudios universitarios. Valencia: Tirant Lo Blanch.

Sánchez-Bayón, A. (2017). Apuntes para una teoría crítica humanista y su praxis económico-empresarial en la posglobalización. Miscelania, 75(147), 305-329.

Retrieved from: https://revistas.comillas.edu/index.php/miscelaneacomillas/article/view/8427/8008

Sánchez-Bayón, A. (2018). Balance de la sociología tras la globalización. Eduser-Revista de Educação, 10(1), $49-68$.

Sánchez-Bayón, A. (2019a). Transición a la economía GIG: claves de sociología empresarial y laboral. Encuentros Multidisciplinares, 62, 1-19. Retrieved from:

https://repositorio.uam.es/bitstream/handle/10486/688493/EM 62 18.pdf?sequence=1\&isAllowed=y

Sánchez-Bayón, A. (2019b). Talentismo: del fin de recursos humanos a la emergencia de talento. Lan HarremanakRevista de Relaciones Laborales, 42, 178-196. DOI: https://doi.org/10.1387/lan-harremanak.21077

Sánchez-Bayón, A. (2020a). Una historia de RR.HH. y su transformación digital: del fordismo al talentismo y la gestión de la felicidad. Revista de la Asociación Española de Especialistas de Medicina del Trabajo, 29(3), 198-214. 
Sánchez-Bayón, A. (2020b). Renovación del pensamiento económico-empresarial tras la globalización: talentism \& happiness economics. Bajo Palabra, 24, 293-318.

Seligman, M. (2011). Flourish: A visionary new understanding of happiness and well-being. New York, NY: Free Press. Tortella, G., Quiroga, G., \& Moral-Arce, I. (2011). ¿El empresario nace o se hace? Educación y empresarialidad en la España contemporánea-Nature or Nurture: Education and entrepreneurship in modern Spain. Revista de Historia Economica-Journal of Iberian and Latin American Economic History, 29(1), 123-153.

DOI: https://doi.org/10.1017/S0212610910000248

Tribe, K. (1995). Professors Malthus and Jones: Political economy at the East India College 1806-1858. The European Journal of the History of EconomicThought, 2(2), 327-354.

DOI: https://doi.org/10.1080/09672569508538573

Trincado, E. (2007). Autogestión y universidad: la historia de un sistema corporativo. Revista Empresa y Humanismo, 11(1), 273-310. Retrieved from:

https://dadun.unav.edu/bitstream/10171/5390/4/Autogesti\%C3\%B3n\%20y\%20universidad.\%20La\%20hi storia\%20de\%20un\%20sistema\%20corporativo.pdf

Valero, J., \& Sánchez-Bayón, A. (2018). Balance de la globalización y teoría social de la posglobalización. Madrid: Dykinson.

Wagner, F. (2005). El mito de la autonomía universitaria. Madrid: Civitas.

Weiss, L. (2003). States in the global economy: Bringing domestic institutions back in. Cambridge, UK: Cambridge University Press. 